www.nature.com/ja

\title{
New isochaetochromin, an inhibitor of triacylglycerol synthesis in mammalian cells, produced by Penicillium sp. FKI-4942: II. structure elucidation
}

\author{
Narihiro Ugaki, Hiroyuki Yamazaki, Ryuji Uchida and Hiroshi Tomoda \\ The structure of a new congener of chaetochromin, an inhibitor of triacylglycerol synthesis in $\mathrm{CHO}-\mathrm{K} 1$ cells produced by \\ Penicillium sp. FKI-4942, was elucidated by spectroscopic methods, including various NMR experiments. Isochaetochromin \\ $A_{1}$ has a bis-naphtho- $\gamma$-pyrone moiety.
}

The Journal of Antibiotics (2012) 65, 21-24; doi:10.1038/ja.2011.106; published online 30 November 2011

Keywords: fungal metabolites; isochaetochromin; naphtho- $\gamma$-pyrone; structure elucidation

\section{INTRODUCTION}

During the course of screening for inhibitors of triacylglycerol synthesis in CHO-K1 cells, a new compound named isochaetochromin $\mathrm{A}_{1}$ was isolated along with structurally related known isochaetochromins $\mathrm{B}_{1}$ and $\mathrm{B}_{2}{ }^{1}$ from the culture broth of Penicillium sp. FKI-4942. These compounds were found to inhibit triacylglycerol synthesis in CHO-K1 cells. The taxonomy of the producing fungus, fermentation, isolation and biological properties of isochaetochromins were described in a previous paper. $^{2}$ In this study, the physico-chemical properties and structure elucidation of isochaetochromin $A_{1}$ are described.

\section{MATERIALS AND METHODS}

General experimental procedures

UV spectra were recorded on a spectrophotometer (8453 UV-Visible spectrophotometer; Agilent Technologies, Santa Clara, CA, USA). IR spectra were recorded on a Fourier transform IR spectrometer (FT-710; Horiba, Kyoto, Japan). Optical rotations were measured with a digital polarimeter (DIP-1000; JASCO, Tokyo, Japan). CD spectra were measured with a spectrometer (J-720; JASCO). ESI-TOF-MS and HRESI-TOF-MS spectra were recorded on a mass spectrometer (JMS-T100LP; JEOL, Tokyo, Japan). Various NMR spectra were measured with a spectrometer (XL-400; Agilent Technologies, Santa Clara, CA, USA).

\section{RESULTS}

Physico-chemical properties of isochaetochromins

The physico-chemical properties of isochaetochromins $A_{1}, B_{1}$ and $B_{2}$ are summarized in Table 1 and have a similar pattern with absorption maxima at 234, 291-292 and $328 \mathrm{~nm}$ in the UV spectra. The IR absorption of isochaetochromins $A_{1}, B_{1}$ and $B_{2}$ at 1342-1348, 1390, $1433-1448,1635$ and $3398-3425 \mathrm{~cm}^{-1}$ suggested the presence of carbonyl and hydroxy moieties in the molecule. These data indicated that isochaetochromin $A_{1}$ is structurally related to isochaetochromins $\mathrm{B}_{1}$ and $\mathrm{B}_{2}$.

Structure of Isochaetochromin $\mathbf{A}_{1}$

The molecular formula of isochaetochromin $\mathrm{A}_{1}$ was determined to be $\mathrm{C}_{30} \mathrm{H}_{26} \mathrm{O}_{10}$ on the basis of HRESI-TOF-MS measurement (Table 1). The ${ }^{13} \mathrm{C}$ NMR spectrum $\left(\mathrm{CDCl}_{3}\right)$ showed 30 resolved signals, which were classified into four methyl carbons, four $s p^{2}$ methine carbons, two $s p^{3}$ methine carbons, two oxygenated $s p^{3}$ methine carbons, eight $s p^{2}$ quaternary carbons, eight oxygenated $s p^{2}$ quaternary carbons and two carbonyl carbons by analysis of the distortionless enhancement by polarization transfer (DEPT) and ${ }^{13} \mathrm{C}-{ }^{1} \mathrm{H}$ HSQC spectra. The ${ }^{1} \mathrm{H}$ NMR spectrum $\left(\mathrm{CDCl}_{3}\right)$ displayed 24 proton signals, which were classified into 12 methyl protons, 8 methine protons and 4 hydroxy protons $(\delta 9.78,9.94,15.32$ and 15.59). Taking the molecular formula into consideration, the presence of two more hydroxy protons was suggested. The connectivity of proton and carbon atoms was established by interpretation of the HSQC spectrum (Table 2). Analysis of ${ }^{1} \mathrm{H}-{ }^{1} \mathrm{H}$ COSY data revealed the presence of two partial structures, as shown in Figure 1. Furthermore, ${ }^{13} \mathrm{C}-{ }^{1} \mathrm{H}$ long-range couplings of ${ }^{2} \mathrm{~J}$ and ${ }^{3} \mathrm{~J}$ observed in the ${ }^{13} \mathrm{C}-{ }^{1} \mathrm{H}$ heteronuclear multiplet bond connectivity (HMBC) spectrum (Figure 2) provided further structural information: $(1)$ the cross peaks from $\mathrm{H}-2(\delta$ 4.52) to C-4 $(\delta 202.6)$ and C-10a $(\delta 156.0)$, from H-3 $(\delta 2.64)$ to C-4 and C-4a $(\delta 101.5)$ and from $3-\mathrm{CH}_{3}(\delta 1.22)$ to $\mathrm{C}-4$ supported the connectivity from $2-\mathrm{CH}_{3}$ $(\delta 1.33)$ to $\mathrm{C}-4 \mathrm{a}$. Considering the number of oxygen atoms present in isochaetochromin $A_{1}$ and the chemical shifts of C-2 ( $\delta$ 75.6) and C$10 \mathrm{a}$, one oxygen atom should be inserted between these carbons. (2) The cross peaks from 5-OH $(\delta 15.59)$ to C-4a, C-5 $(\delta 165.6)$ and C-5a $(\delta$ 105.7), from 6-OH $(\delta$ 9.94) to C-5a, C-6 $(\delta$ 158.6) and C-7 $(\delta$ 100.1), from H-7 $(\delta$ 6.56) to C-5a, C-6, C-8 $(\delta$ 161.2) and C-9 
Table 1 Physico-chemical properties of isochaetochromins

\begin{tabular}{|c|c|c|c|}
\hline & Isochaetochromin $A_{1}$ & Isochaetochromin $B_{1}$ & Isochaetochromin $B_{2}$ \\
\hline Appearance & Yellow powder & Yellow powder & Yellow powder \\
\hline Molecular weight & 546 & 546 & 546 \\
\hline \multicolumn{4}{|l|}{ HRESI-TOF-MS (m/z) } \\
\hline Calcd: & $569.1423(\mathrm{M}+\mathrm{Na})^{+}$ & $569.1423(\mathrm{M}+\mathrm{Na})^{+}$ & $569.1423(\mathrm{M}+\mathrm{Na})^{+}$ \\
\hline$[\alpha]_{5}^{26}$ & $-229^{\circ}\left(c=0.1, \mathrm{CHCl}_{3}\right)$ & $+142^{\circ}\left(c=0.1, \mathrm{CHCl}_{3}\right)$ & $-548^{\circ}\left(c=0.10, \mathrm{CHCl}_{3}\right)$ \\
\hline $\mathrm{IR}(\mathrm{KBr}) v_{\max }\left(\mathrm{cm}^{-1}\right)$ & $3406,1635,1448,1390,1342$ & $3398,1635,1441,1390,1344$ & $3425,1635,1433,1390,1348$ \\
\hline
\end{tabular}

Table $2{ }^{1} \mathrm{H}(400 \mathrm{MHz})$ and ${ }^{13} \mathrm{C}$ NMR $(100 \mathrm{MHz})$ chemical shifts of isochaetochromins in $\mathrm{CDCl}_{3}$

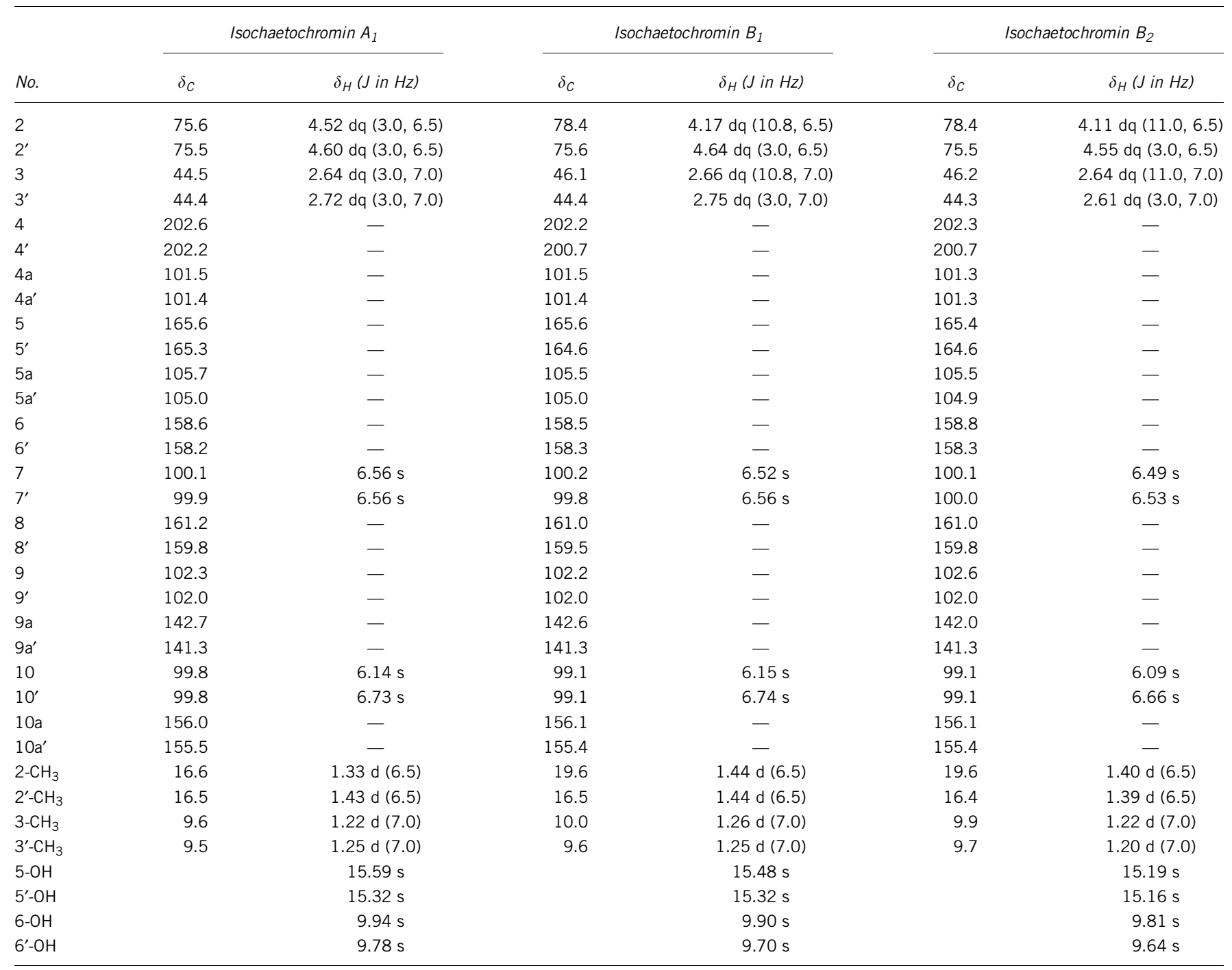

$(\delta$ 102.3) and from H-10 $(\delta$ 6.14) to C-4a, C-5a, C-9, C-9a $(\delta 142.7)$ and $\mathrm{C}-10 \mathrm{a}$ supported the existence of the naphthalene ring (C-4a to C-10a). Considering the chemical shift of C-8 and molecular formula, one hydroxy group should be connected at C-8; thus, the existence of the naphtho- $\gamma$-pyrone (naphtho- $\gamma$-dihydropyrone) unit in isochaetochromin $\mathrm{A}_{1}$ was confirmed as shown in Figure 2. The NMR data suggested the presence of one more naphtho- $\gamma$-pyrone in isochaetochromin $A_{1}$. Fortunately, the naphtho- $\gamma$-pyrone unit (C-2' to $C-10^{\prime}$ a) 


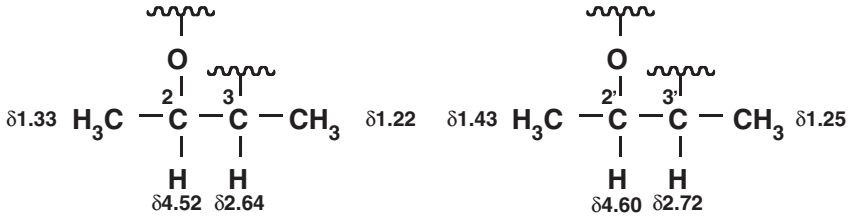

I

II

Figure 1 Partial structures of isochaetochromin $A_{1}$.
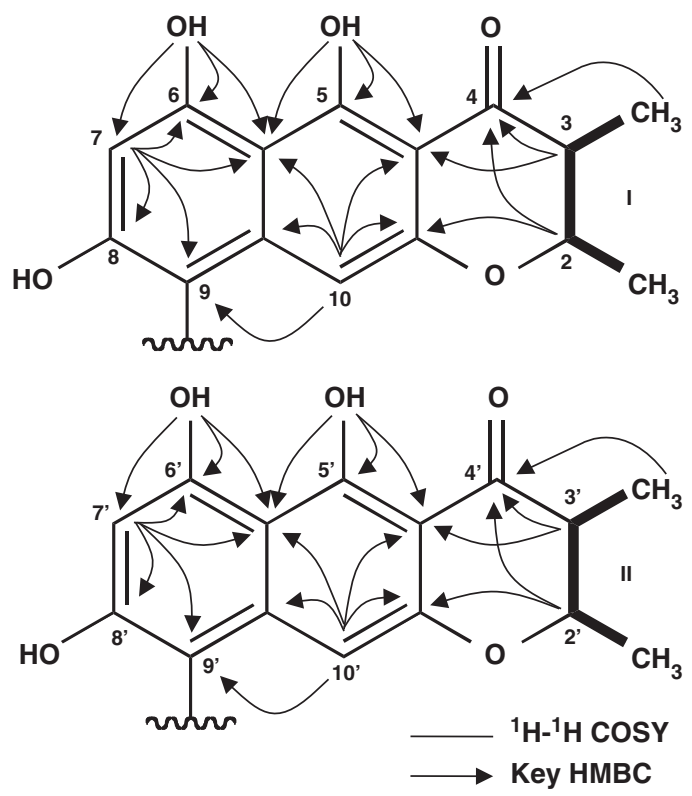

Figure $2{ }^{1} \mathrm{H}-{ }^{1} \mathrm{H}$ COSY and ${ }^{13} \mathrm{C}-{ }^{1} \mathrm{H}$ HMBC experiments of isochaetochromin $A_{1}$. was assigned in the same way as the first naphtho- $\gamma$-pyrone unit (C-2 to C-10a). Taking all these findings together, the planar structure of isochaetochromin $A_{1}$ was elucidated to be a symmetrical dimer of the naphtho- $\gamma$-pyrone, as shown in Figure 3.

The relative stereochemistry at $\mathrm{C}-2, \mathrm{C}-3, \mathrm{C}-2^{\prime}$ and $\mathrm{C}-3^{\prime}$ of the $\gamma$-pyrone skeleton was investigated by the $J$ values and NOE experiments. The $J$ values $\left(J_{2-3}=3.0 \mathrm{~Hz}\right.$ and $\left.J_{2^{\prime}-3^{\prime}}=3.0 \mathrm{~Hz}\right)$ of isochaetochromin $A_{1}$ indicated that both the vicinal methyl groups are cis. ${ }^{1}$

\section{Key NOE}
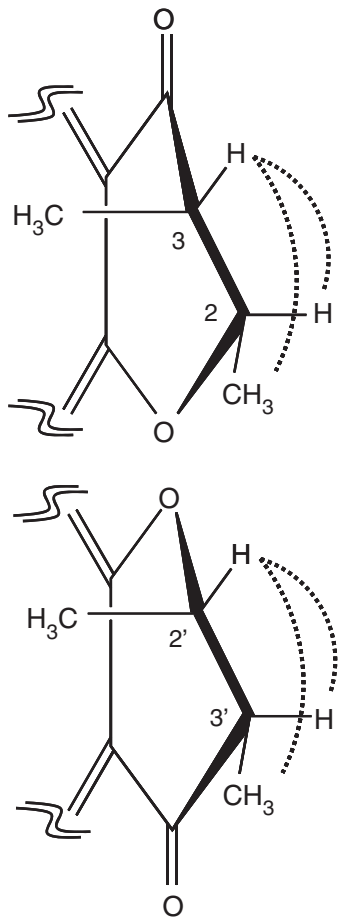

Figure 4 NOE experiments of isochaetochromin $A_{1}$.

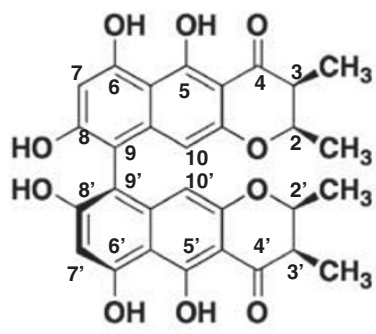

Isochaetochromin $\mathrm{A}_{1}$<smiles>C[C@@H]1Oc2cc3c(O)cc(O)c(-c4c(O)cc(O)c5c(O)c6c(c(O)c45)C(=O)[C@H](C)[C@@H](C)O6)c3cc2O[C@@H]1C</smiles>

Chaetochromin A

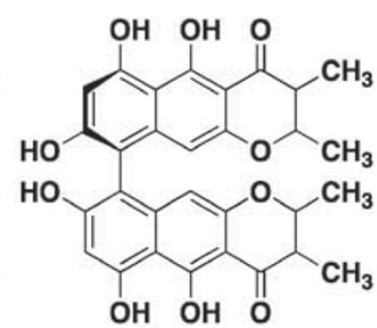

Isochaetochromin $B_{1}$<smiles>CC1Oc2cc3c(C(=O)C(C)C(C)C)c(O)c(O)cc(O)c-3c2-c2cc3c(c(O)c2C(O)=CC(O)=C3O)C(=O)C(C)C(C)O1</smiles>

Ustilaginoidin D<smiles></smiles>

Isochaetochromin $\mathrm{B}_{2}$<smiles>CC1Oc2cc3c4c(O)c5c(c(O)c4c(-c4c(O)cc(O)c6c(O)c(O)cc(O)c46)c-3c(O)c(O)c2C1=O)OC(C)C(C)C5=O</smiles>

Chaetochromin B

Figure 3 Structures of isochaetochromins $A_{1}, B_{1}$ and $B_{2}$, chaetochromin $A$, ustilaginoidin $D$ and chaetochromin $B$. 
Furthermore, NOEs were observed between $\mathrm{H}-2$ and $\mathrm{H}-3$, between 2$\mathrm{CH}_{3}$ and $\mathrm{H}-3$, between $\mathrm{H}-3$ and $\mathrm{H}-2 / 2-\mathrm{CH}_{3}$, between $\mathrm{H}-2^{\prime}(\delta 4.60)$ and $\mathrm{H}-3^{\prime}(\delta 2.72) / 3^{\prime}-\mathrm{CH}_{3}(\delta 1.25)$, between $\mathrm{H}-3^{\prime}$ and $\mathrm{H}-2^{\prime}$ and between $3^{\prime}-$ $\mathrm{CH}_{3}$ and $\mathrm{H}-2^{\prime}$ (Figure 4). From these data, the relative stereochemistry of isochaetochromin $A_{1}$ was elucidated as shown in Figure 3.

To elucidate the absolute axial stereochemistry, the specific rotation and the $\mathrm{CD}$ data of isochaetochromin $\mathrm{A}_{1}$ was compared with those reported for isochaetochromins $B_{1}$ and $B_{2} \cdot{ }^{1}$ The specific rotation of isochaetochromin $\mathrm{A}_{1}\left(-229^{\circ}\right)$ showed a negative value, as did isochaetochromin $\mathrm{B}_{2}\left(-543.9^{\circ}, \mathrm{a} R\right)$, but isochaetochromin $\mathrm{B}_{1}$ $\left(+142.6^{\circ}\right.$, aS $)$ showed a positive value. Furthermore, the CD spectrum of isochaetochromin $A_{1}$ showed the first negative cotton effect at $292 \mathrm{~nm}$ and the second positive cotton effect at $268 \mathrm{~nm}$. These spectra conformed to those of isochaetochromin $\mathrm{B}_{2}$. Accordingly, the respective absolute axis stereochemisitry of isochaetochromin $A_{1}$ was elucidated to be $\mathrm{a} R$.

\section{DISCUSSION}

A new isomer named isochaetochromin $A_{1}$ was isolated along with known isomers isochaetochromins $\mathrm{B}_{1}$ and $\mathrm{B}_{2}{ }^{1}$ from the culture broth of Penicillium sp. FKI-4942 as inhibitors of TG synthesis in CHO-K1 cells. ${ }^{2}$ Isochaetochromins $\mathrm{B}_{1}$ and $\mathrm{B}_{2}$ were reported to be produced by Fusarium sp., ${ }^{1}$ whereas all the isochaetochromins described in this study were produced by Penicillium $\mathrm{sp}^{2}$

From the structure elucidation of isochaetochromins $A_{1}, B_{1}$ and $B_{2}$, these compounds have the same planar structures, although the structural difference among the isomers comes from the combination of the stereochemistry at $2 / 2^{\prime}$ and $3 / 3^{\prime}$ methyl residues and from the $9 /$ $9^{\prime}$ axis $(\mathrm{a} S$ or $\mathrm{a} R)$ of the two monomers. Theoretically, there are 16 isomers for the same structure of this dimer. Among them, six isomers, chaetochromins $\mathrm{A}$ and $\mathrm{B},{ }^{3,4}$ ustilaginoidin $\mathrm{D}^{6}$ and isochaetochromins $A_{1}, B_{1}$ and $B_{2}^{1,2}$ (Figure 3 ), have been reported so far. Chaetochromin A is a symmetrical dimer having two trans-2,3dimethyl groups on the 5,6,8-trihydroxy-naphtho- $\gamma$-pyrone ring, and the absolute stereochemistry was established by CD and X-ray crystallography of $p$-bromobenzoate derivative. ${ }^{5}$ Ustilaginoidin $\mathrm{D}$ is also a symmetrical dimer having two trans-2,3-dimethyl groups, and the 9/9' axial stereochemistry was elucidated to be $\mathrm{a} R$ by comparative $\mathrm{CD}$ spectroscopy. However, the absolute stereochemistry was not determined. ${ }^{6}$ On the other hand, chaetochromin B and isochaetochromins $\mathrm{B}_{1} / \mathrm{B}_{2}$ were unsymmetrical dimers having one trans-2,3-dimethyl group and one cis-2,3-dimethyl group, and these axial stereochemistries were elucidated to be $\mathrm{a} S, \mathrm{a} S$ and $\mathrm{a} R$ by $\mathrm{CD}$ spectroscopy, respectively. However, it appeared difficult to elucidate the complete stereochemistry of these compounds. It would be done by X-ray crystallographic Analysis. In fact, the complete stereochemistry of chaetochromin $\mathrm{B}^{3}$ and isochaetochromins $\mathrm{B}_{1} / \mathrm{B}_{2}{ }^{1}$ has not been reported to date.

This series of isomers was produced by fungal genera Chaetomium, ${ }^{3,4,7}$ Claviceps, $^{6}$ Fusarium $^{1}$ and Penicillium. ${ }^{2}$ As they were completely different in taxonomical characteristics, these fungi share the similar biosynthetic genes to produce naphtho- $\gamma$-pyrones. Distinct isomers will be further isolated from the culture broth of these fungi.

\section{ACKNOWLEDGEMENTS}

We express our thanks to Ms N Sato for performing NMR experiments, and Dr K Nagai and Ms A Nakagawa for measuring mass spectra. This work was supported by a grant-in-aid for Scientific Research (B) 18390008 (to HT) from the Ministry of Education, Culture, Sports, Science and Technology of Japan.

1 Singh, S. B. et al. Four novel bis-(naphtho-gamma-pyrones) isolated from Fusarium species as inhibitors of HIV-1 integrase. Bioorg. Med. Chem. Lett. 13, 713-717 (2003).

2 Ugaki, N. et al. New isochaetochromin, an inhibitor of triacylglycerol synthesis in mammalian cells, produced by Penicillium sp. FKI-4942: I. Taxonomy, fermentation, isolation and biological properties. J. Antibiot. 65, 15-19 (2012).

3 Koyama, K. \& Natori, S. Chaetochromins B, C and D, bis(naphtho- $\gamma$-pyrone) derivatives from Chaetomium gracile. Chem. Pharm. Bull. 35, 578-584 (1987).

4 Sekita, S., Yoshihira, K. \& Natori, S. Chaetochromin, a bis(naphthodihydropyran-4-one) mycotosin from Chaetomium thielavioideum: application of ${ }^{13} \mathrm{C}-{ }^{1} \mathrm{H}$ long-range coupling to the structure elucidation. Chem. Pharm. Bull. 28, 2428-2435 (1980).

5 Koyama, K., Natori, S. \& litaka, Y. Absolute configurations of chaetochromin A and related bis(naphtho- $\delta$-pyrone) mold metabolites. Chem. Pharm. Bull. 35, 4049-4055 (1987).

6 Koyama, K. \& Natori, S. Further characterization of seven bis(naphtho- $\gamma$-pyrone) congeners of ustilaginoidins, coloring matters of Claviceps virens (Ustilaginoidea virens). Chem. Pharm. Bull. 36, 146-152 (1988).

7 Sekita, S. et al. Mycotoxin production by Chaetomium spp. and related fungi. Can. J. Microbiol. 27, 766-772 (1981). 